Jurnal Ilmiah Mahasiswa Kendali dan Listrik
Vol. xx, No. xx, Mounth 2020, page-page. $\mathbf{x} \sim \mathbf{x x}$
E-ISSN: 2723-598X
DOI: https://doi.org/10.33365/jimel.v1i1

\title{
SISTEM KENDALI OTOMATIS PADA PINTU PERLINTASAN KERETA API
}

\author{
Ahmad Hermawan ${ }^{1}$, Sampurna Dadi ${ }^{2}$, Ahmad Jayadi ${ }^{3}$ \\ ${ }^{1}$ Fakultas Teknik dan Ilmu Komputer. Universitas Teknokrat Indonesia) \\ ${ }^{2}$ Fakultas Teknik dan Ilmu Komputer. Universitas Teknokrat Indonesia \\ ${ }^{3}$ Fakultas Teknik dan Ilmu Komputer. Universitas Teknokrat Indonesia
}

Email: ahmadhermawan@gmail.com ${ }^{1}$,sampurna.go@teknokrat.ac.id², ahmadjayadi@teknokrat.ac.id ${ }^{3}$

\begin{tabular}{lll}
\hline Received: (date month year) & Accepted: (date month year) & Published : (date month year ) \\
\hline
\end{tabular}

\begin{abstract}
In making this simulation, the writer aims to design a system to facilitate the work of operating crossroad latches and aisle lights on railroad tracks which sometimes still require personnel, so it often occurs due to negligence in operating them which causes accidents on the railroad crossing. For this reason, researchers designed an automatic control system at railroad crossings using a weight sensor system which is expected to help streamline the operation of railroad crossings.

The way this tool works is by utilizing Arduino microcontroller, Infrared sensor and Ultrasonic sensor as data input. The way this prototype works is the Load Cell sensor whose function is to activate the Infra Red 1 sensor to provide input when a train passes and the crossing gate will open, and the Infra Red 2 sensor will close the crossing latch when the train has passed the crossing and give a message of thanks has obeyed traffic. When a train enters the hallway, the Ultrasonic sensor will turn on, controlling the led to adjust the train's passing by repetitive work processes.
\end{abstract}

Keywords: Arduino, Lcd, Sensor Infrared, Sensor Ultrasonic, Sensor Load Cell

\begin{abstract}
Abstrak
Dalam Pembuatan simulasi ini penulis bertujuan untuk merancang sebuah sistem dalam memudahkan pekerjaan dalam mengoprasikan palang pintu perlintasan dan lampu lorong pada rel kereta api yang terkadang masih memerlukan tenaga pegawai sehingga sering terjadi karena kelalaian dalam mengoprasikannya yang menyebabkan kecelakaan di jalur perlintasan kereta api. Untuk itu peneliti melakukan perancangan terhadap sistem kendali otomatis pada perlintasan kereta api menggunakan sistem sensor berat yang diharapkan bisa membantu mengefisienkan dalam mengoprasikan palang pintu perlintasan kereta api.

Cara kerja alat ini yaitu dengan memanfaatkan mikrokontroler arduino, sensor Infrared dan sensor Ultrasonic sebagai pemberi inputan data. Cara kerja prototipe ini yaitu sensor Load Cell yang fungsinya mengaktifkan sensor Infra Red 1 untuk memberi inputan saat kereta api melintas dan palang pintu perlintasan akan membuka, dan sensor Infra Red2 akan menutup palang pintu perlintasan saat kereta api sudah melewat palang pintu perlintasan dan memberi pesan terimakasih telah mematuhi lalu lintas. Ketika kereta api memasuki lorong sensor Ultrasonic akan menghidupkan, mengontrol led menyesuaikan jalannya kereta api yang melintas dengan proses kerja berulang-ulang
\end{abstract}

Kata Kunci: Arduino, Lcd , Sensor Infrared,Sensor Ultrasonic, Sensor Load Cell

\section{To cite this article:}

Authors. (Year). Title of the article. Jurnal Ilmiah Mahasiswa Kendali dan Listrik, Vol(1), Page-Page. 


\section{PENDAHULUAN}

Salah satu alat transportasi darat adalah Kereta Api, hal ini dikarenakan kereta api memiliki kelebihan lain terutama sebagai solusi dari masalah kemacetan. Terlepas dari hal itu, Kecelakaan pada jalur kereta api diakibatkan oleh tidak terawatnya palang pintu perlintasan kereta api dan bahkan telah hancur. Sering kali berita menyiarkan kecelakaan kereta api terjadi di perlintasan kereta api karena tidak adanya pengawasan palang pintu perlintasan kereta api. Salah satu contoh alat transportasi darat yang paling dominan dan diandalkan di Indonesia adalah kereta api [1]. Penyebab kecelakaan lalu lintas pada persimpangan rel kereta api pada umumnya terjadi karena tidak adanya sarana dan prasarana (palang pintu perlintasan) dan kelalaian petugas penjaga dalam melakukan tugasnya. Oleh karena itu perlu dirancang palang pintu perlintasan kereta api otomatis. Palang pintu perlintasan kereta api merupakan salah satu sarana prasarana kereta api [2][3].

Untuk penerapan teknologi pengaman transportasi di Indonesia diperlukan suatu teknologi yang murah dan sederhana sehingga dapat digunakan dengan harga yang terjangkau. Salah satu teknologi yang dapat diterapkan yaitu pengontrolan secara otomatis kereta api ketika berjalan dalam rel, supaya dapat mempermudah manusia dalam menjalankan tugas [4]. Menurut Direktur Keselamatan Kereta Api KemenHub RI, Bapak Edi Nursalam, ada 4.600 tidak ada palang pintu [5].

\section{TELAAH PUSTAKA}

Pada penelitian yang telah dilakukan diantaranta adalah menjelaskan bagaimana menerapkan system keamanan pada perlintasan Kereta Api [6]. Untuk membuat purwarupa di butuhkan beberapa perangkat.

\section{ALAT DAN BAHAN PENELITIAN}

Sensor Ultrasonic adalah sensor yang memiliki dua perangkat yaitu sebagai Transmiter dan Receiver. Transmitter berfungsi mengirim sinyal, dan ketika ada yang menghalangi sinyal tersebut akan kembali dan di terima oleh Receiver. Dalam pengembangan protoipe pemandu parkir mobil sensor ultrasonik berfungsi sebagai sensor jarak antara kendaraan dan objek lain [7].

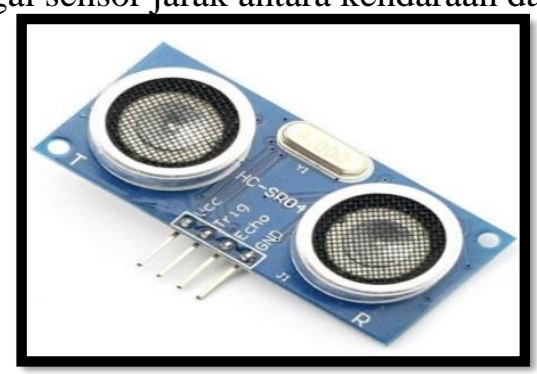

Gambar 2 Sensor Ultrasonic

Motor servo adalah sebuah perangkat atau aktuator putar (motor) yang dirancang dengan sistem kontrol umpan balik loop tertutup (servo), sehingga dapat di set-up atau di atur untuk menentukan dan memastikan posisi sudut dari poros output motor. Motor servo merupakan perangkat yang terdiri dari motor DC, serangkaian gear, rangkaian kontrol dan potensiometer. Penggunaan motor dengan gear box atau yang biasa disebut dengan servo pada alat ini digunakan sebagai penutup dan pembuka pintu [8][9].

Mikrokontroller merupakan pengembangan dari Mikroprosesor yang merupakan sebuah chip atau IC yang hanya memiliki Central Processing Unit (CPU) di dalamnya. Mikroprosesor dalam perkembangan komputer digital disebut sebagai Central Processing Unit (CPU) yang bekerja sebagai pusat pengolah dan pengendalian pada sistem komputer mikro. Sebuah mikroprosesor tersusun dari 
tiga bagian penting yaitu : Arithmetic Logic Unit (ALU), Register Unit (RU), dan Control Unit (CU) [10].

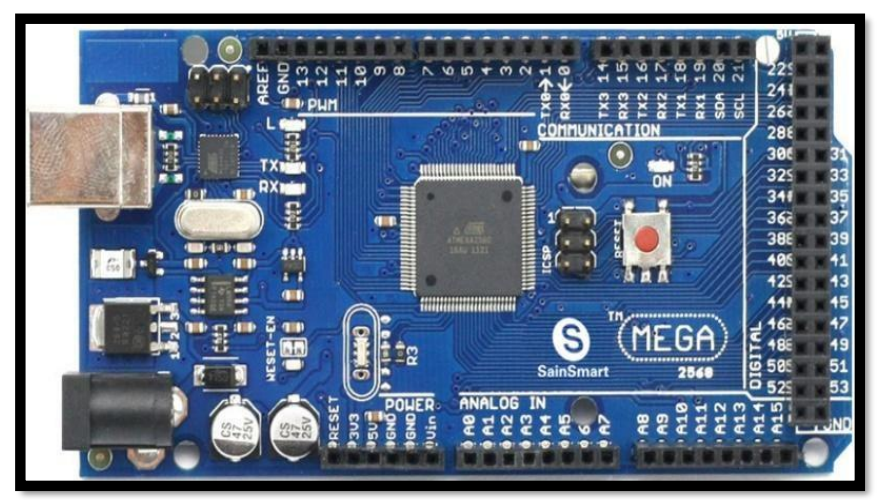

Gambar 2 Mikrokontroller

Sensor PIR (Passive Infrared) adalah suatu alat yang berfungsi untuk mengindra atau menangkap suatu besaran fisis (temperatur suhu tubuh manusia) dan merubahnya kebentuk sinyal listrik. Sesuai namanya, Passive Infrared, sensor ini bersifat pasif. Sensor ini menerima sinyal infrared yang dipancarkan oleh suatu objek yang bergerak [11], [12].

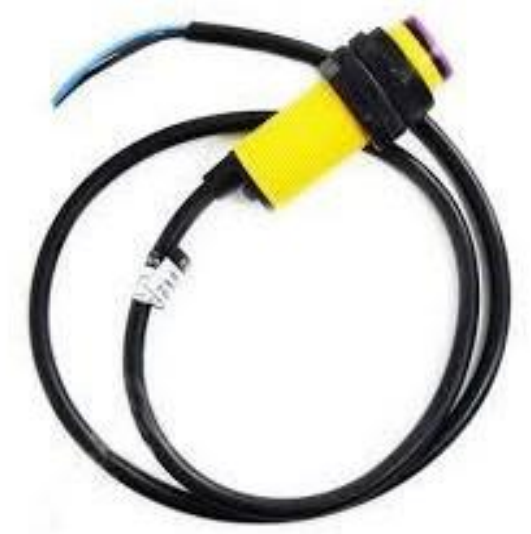

Gambar 3 Sensor Infrared

\section{METODE PENELITIAN}

Pada penelitian ini diawali terlebih dahulu dengan observasi lapangan yang kemudian dilanjutkan dengan perancangan alat. Tahapan penelitian yang dilakkan diantaranya:

1. Analisa Kebutuhan;

2. Perancangan Alat;

3. Pengujian dan Analisis

Proses perancangan alat bertujuan sebagai berikut :

1. Agar alat yang dihasilkan akan sesuai dengan yang diharapkan.

2. Untuk memilih komponen-komponen yang paling tepat.

3. Untuk menentukan kesalahan-kesalahan atau kendala eror yang terjadi.

4. Meminimalis biaya namun dengan alat yang hasilnya memuaskan

Pada gambar diagram blok di bawah ini menjelaskan tentang cara kerja alat secara keseluruhan mulai dari input, proses, hingga output dalam diagram blok ini hanya terdapat hubungan jalur antara blok-blok saja, tetapi tiap masing-masing blok terdapat komponen utama dan komponen pendukung. 


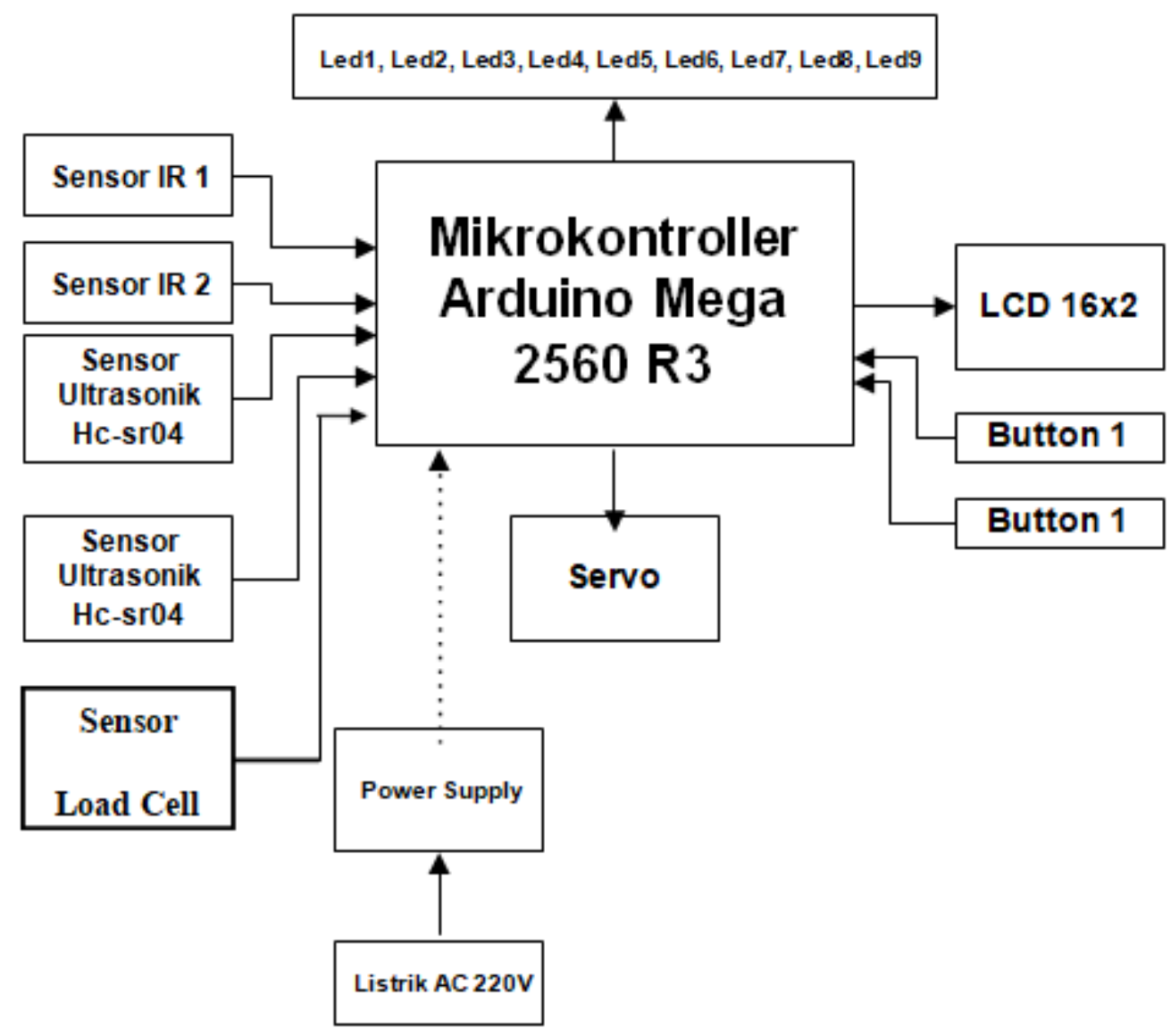

Gambar 4 Diagram Blok Kerja Alat

Dari blok diagram di atas dapat dijelaskan fungsi masing-masing blok sebagai berikut :

1. Listrik AC $220 \mathrm{~V}$ dari PLN sebagai sumber tegangan yang mensuplay tegangan pada alat ini.

2. Sensor IR 1, IR 2 dan Ultrasonik sebagai sensor pendeteksi adanya kereta yang melalui lintasan tersebut yang nantinya akan memberikan input perintah yang selanjutnya untuk dikelola mikrokontroller agar sistem dapat berjalan.

3. Led 1 sampai dengan led 9 berguna sebagai led yang menerangi terowongan sebagai output dari sistem.

4. Servo digunakan sebagai simulasi palang pintu kereta api.

5. Lcd 16x2 digunakan sebagai media pesan selamat datang yang menunjukan bahwa kereta telah memasuki area tertentu.

6. Button digunakan untuk menghidupkan ataupun mematikan lampu lorong dan membuka dan metutup servo ketika terjadi sebuah kesalahan sistem.

7. Sersor ultrasonic digunakan sebagai pendeteksi keberadaan kereta dan manusia ketika melintasi lorong rel.

8. Sensor load cell digunakan sebagai pendeteksi berat kereta yang melintas di rel yang terasang sensor load cell. 


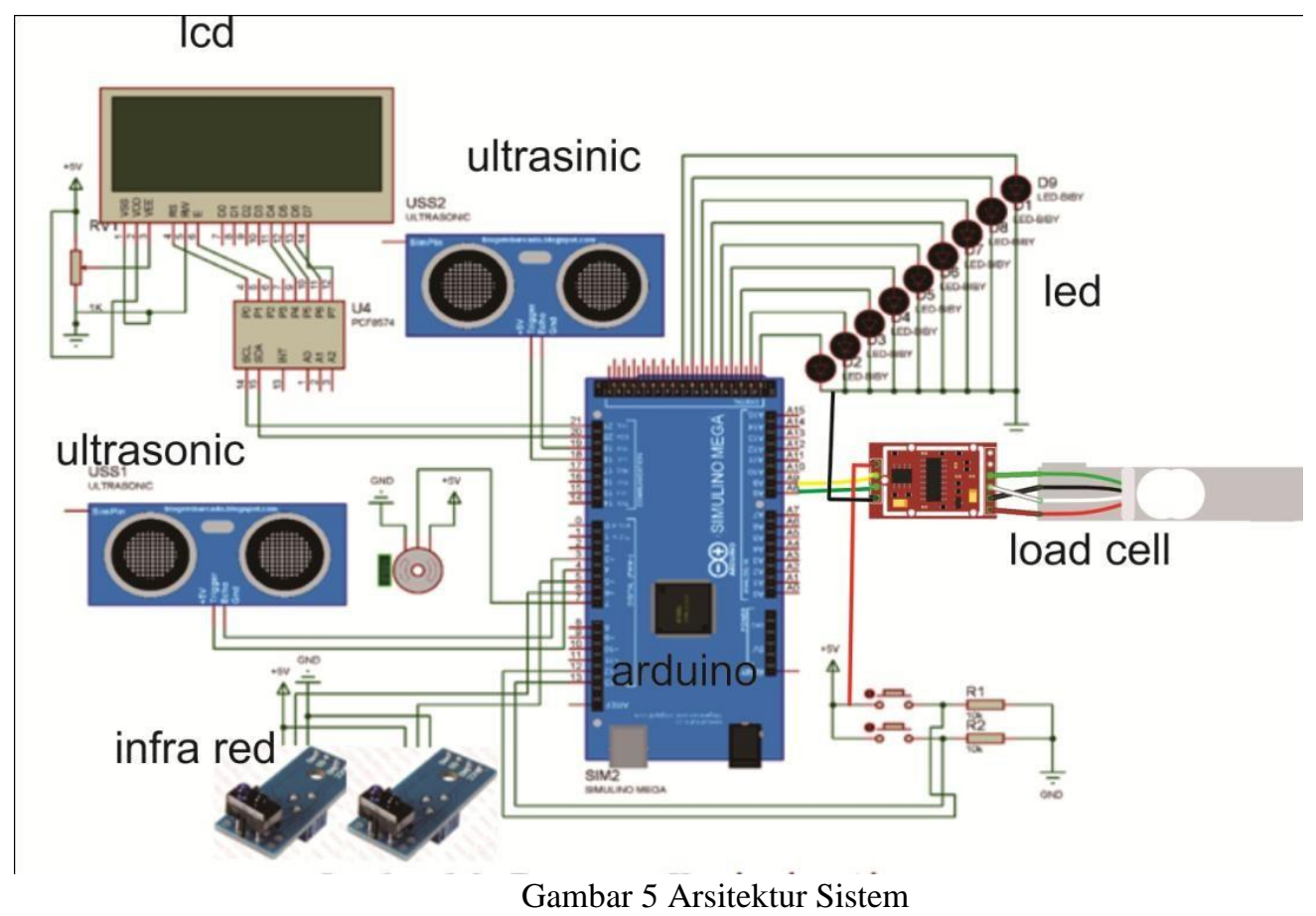

\section{HASIL DAN PEMBAHASAN}

Tujuan pengujian mikrokontroller merupakan proses yang dibutuhkan untuk mengetahui apakah system sudah bekerja sesuai dengan desain dan rancangan yang telah dilakukan sebelumnya.

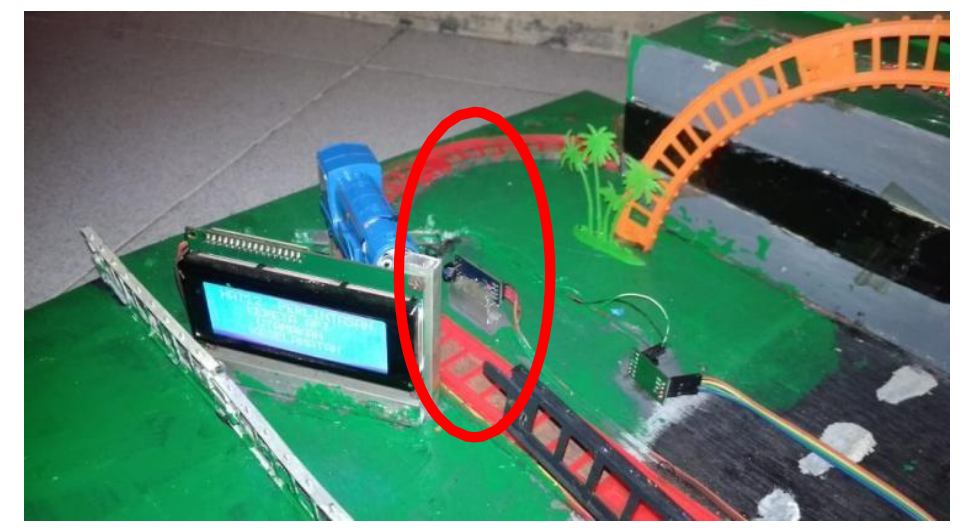

Gambar 6 Prototipe Alat

Sistem kerja dari keseluruhan alat adalah bermula setelah seluruh rangkaian dihubungkan dengan sumber tegangan atau catu dayauntukmensupply daya ke seluruh komponen ketika ada kereta yang lewat pada rel kereta maka akan mengenai sensor berat HX7010 dan memberikan tekanan pada bantalan rel yaitu beban 0,1 $\mathrm{kg}$ (kereta miniatur berat hanya $0,1 \mathrm{~kg}$ ) dan mengenai sensor ir 1 maka semua komponen mati termasuk led, lcd tetapi palang pintu kereta atau servo akan menutup atau posisi 900, ketika kereta mengenai sensor ir 2 maka palang pintu kereta kembali membuka atau kembali ke posisi 00 dan lcd akan menampilkan "hati-hati perlintasan kereta api utamakan keselamatan", lalu ketika sensor ultrasonik mendeteksi kereta ada kereta di terowongan yang melintas lampu led akan hidup secara berurutan sesuai majunya kereta lewat. Berikut adalah tabel hasil pengujian keseluruhan alat 


\section{SIMPULAN}

Dengan memanfaatkan mikrokontroler arduino, sensor Infra Red, sensor berat load cell dan sensor Ultrasonic system telah bekerja sesuai dengan perancangan yang di lakukan. Cara kerja prototipe inisensor Infrared memberikan masukan ke mikrokontroller untuk menutup palang pintu saat sensor load cell ada beban. Pada saat sensor loadcell telah kembali ke keadaan semula maka palang pitu akan membuka secara otomatis.

\section{DAFTAR PUSTAKA}

[1] R. Sarnia Rizki Oktareza, Yusnita, "Simulasi Sistem Keamanan Palang Pintu Perlintasan Kereta Api Menggunakan LabVIEW,” J. Online Mhs. Fak. Tek. Univ. Riau, vol. 2, 2015.

[2] Dewi Desdemona, "RANCANG BANGUN PALANG PINTU PERLINTASAN KERETA API OTOMATIS BERBASIS ATMEGA8535," Tek. Elektro Ind., vol. Vol. 1, no. No.3, p. ISSN: 2302-3309, 2013, [Online]. Available:

http://ejournal.unp.ac.id/students/index.php/tei/article/view/881.

[3] D. D. Febriyanto Febriyanto, "Perancangan Palang Pintu Kereta Otomatis Menggunakan Mikrokontroler Atmega 16," J. Inf. Syst. Informatics Comput., vol. 2, no. ISSN 2597-3673, 2018, [Online]. Available:

http://journal.stmikjayakarta.ac.id/index.php/jisicom/article/view/16.

[4] S. Ari Beni Santoso, Martinus, "Pembuatan Otomasi Pengaturan Kereta Api, Pengereman, Dan Palang Pintu Pada Rel Kereta Api Mainan Berbasis Mikrokontroler," J. FEMA, vol. 1, pp. 1623, 2013.

[5] Ani Nursalikah, "80 Persen Perlintasan Kereta di Indonesia Liar,” Republika, 2018. https://republika.co.id/berita/p71st9366/80-persen-perlintasan-kereta-di-indonesia-liar.

[6] B. P. Pangestu, B. H. Prasetio, and G. E. Setyawan, "Implementasi Kendali Palang Pintu Kereta Api Menggunakan IR Sensor dan NRF24L01," J. Pengemb. Teknol. Inf. dan Ilmu Komput., vol. 1, no. 4, pp. 282-291, 2017.

[7] K. Pindrayana, R. Indra Borman, B. Prasetyo, and S. Samsugi, "Prototipe Pemandu Parkir Mobil Dengan Output Suara Manusia Mengunakan Mikrokontroler Arduino Uno," CIRCUIT J. Ilm. Pendidik. Tek. Elektro, vol. 2, no. 2, pp. 71-82, 2018, doi: 10.22373/crc.v2i2.3705.

[8] A. I. Yusuf, S. Samsugi, and F. Trisnawati, "Sistem Pengaman Pintu Otomatis Dengan Mikrokontroler Arduino Dan Module Rf," vol. 1, no. 1, pp. 1-6, 2020.

[9] R. Dikky Auliya Saputra, Amarudin, "Rancang Bangun Alat Pemberi Pakan Ikan Otomatis Menggunakan Pewaktu," J. Ilm. Tek. Pertan., vol. 7, no. 1, pp. 1-76, 2015.

[10] Idhar, "Embedded systems and robotics," in Embedded System, 1st ed., vol. 23, no. 3, Idhar, Ed. Makasar: UNM, 2017, pp. 173-173.

[11] S. D. R. I Komang, "Rancang Bangun Sistem Pengunci Loker Otomatis Dengan Kendali Akses Menggunakan Rfid Dan Sim 800L,” J. Ilm. Mhs. Kendali dan List., vol. 1, no. 1, pp. 33-41, 2020.

[12] R. H. Zain, "Sistem Keamanan Ruangan Menggunakan Sensor Passive Infra Red (PIR) Dilengkapi Kontrol Penerangan Pada Ruangan Berbasis Mikrokontroler Atmega8535 Dan Real Time Clock Ds1307," J. Teknol. Inf. dan Pendid, vol. 6, no. 1, pp. 45-54, 2013. 